CONVERSANDO

COM A MÍDIA

\title{
O INSULTO
}

ADRIANA SCOZ DA CUNHA LIMA

MARIA GABRIELA MANTAUT LEIFERT

ROBERTO RICARDI COSTARD

Instituto Noos
Título original: L'Insulte.

Direção: Ziad Doueiri.

Produção: Antoun Sehnaoui, Jean Bréhat, Julie Gayet, NadiaTurincev, Rachid Bouchareb.

Líbano/Bélgica/Chipre/França/EUA: Imovision, 2017.

Uma bobina cinematográfica (112 min); legenda; color.

“Todos nós compartilhamos este mundo apenas por um breve período de tempo. A questão é se vamos passar nosso tempo nos focando naquilo que nos divide, ou se vamos engajar num esforço - esforço sustentado - para encontrar um terreno comum, para nos focar no futuro que buscamos para nossos filhos e para respeitar a dignidade de todos os seres humanos." (Discurso de Barack Obama, 4 de junho de 2009)

nstigante, envolvente, provocante, sensível, humano, complexo são algumas palavras que caracterizam o filme $\mathrm{O}$ Insulto. A história se passa no Líbano e envolve: um mecânico de automóveis, Toni, filiado ao partido cristão; sua mulher, grávida da primeira filha, e um trabalhador da construção civil, Yasser, palestino (em situação de refúgio) que estava fazendo um conserto no bairro do casal. Em um determinado momento, Toni, ao regar as plantas na varanda, molha Yasser que estava embaixo, na calçada, executando uma obra no edifício. Ambos têm um desentendimento e Yasser insulta Toni. Desde o início, Toni pede que Yasser se desculpe e isso não ocorre. A situação se agrava chegando à violência física e ambos iniciam um pleito judicial, que acaba em proporções nacionais ao fazer emergir todos os ressentimentos nacionalistas e políticos dessa questão.

O tema abordado por esse filme é extremamente atual, pois traz à tona as desigualdades econômicas, sociais, étnicas, políticas e territoriais que colocam as pessoas em condição de extrema vulnerabilidade e incerteza. Esta situação de injustiça social causa um sentimento de insegurança e medo que se propaga por toda a sociedade, tornando-se uma preocupação de ordem mundial.

O filme retrata a política adotada pelo governo libanês e uma de suas graves implicações: o partido cristão contra o asilo oferecido aos palestinos; por outro lado, os refugiados palestinos.

A sutileza com que somos levados a transitar de uma questão macrossocial ao microcosmos relacional é impactante, quer dizer, a capacidade do enredo de transformar um gesto tão simples e singelo em porta-voz e metáfora poderosa da dor, humilhação e sofrimento humano. Ao longo da narrativa, o diretor nos conduz nas histórias pessoais de cada um dos personagens como uma possibilidade do entendimento desta trama.

O que o filme deixa evidente e trabalha com maestria é a importância do acesso às diversas histórias vividas por trás do conflito. Corrobora a visão que se neces- 
sidades e motivações subjacentes ao ato, quando não são expressas, acirram as diferenças e fomentam o ódio entre as pessoas. No contexto acima, podemos fazer

um link com o trabalho proposto pela mediação transformativa trazida por Bush e Folger (1994) que possibilita às pessoas a expressão de suas histórias de vida e de novas visões sobre o conflito por meio do diálogo e da escuta.

Toni somente queria um pedido de desculpas, mas acabou responsável por situações de maior agressão, inviabilizando o que ele mais desejava: uma retratação.

$\mathrm{O}$ conflito pôde ser resolvido quando vieram à tona as reais motivações que sustentaram as posições polarizadas dos atores da discórdia. Ao conhecer reciprocamente as suas histórias, os protagonistas tiveram acesso às vivências de dor e sofrimento envolvendo as disputas das respectivas origens étnicas. Dessa forma, aquela situação de vítima e ofensor foi desfeita, pois ambos se perceberam vítimas de uma tragédia social compartilhada.

Um valioso recurso que pode ser utilizado em uma situação semelhante a apresentada por esse filme é a mediação de conflitos. Ela auxilia a escuta do outro e de nós mesmos; o diálogo com o coração aberto; a resolução de problemas de modo criativo; a negociação colaborativa; o perdão a si próprio e, consequentemente, a reconciliação com nós mesmos, com o outro e com o mundo.

\section{REFERÊNCIAS}

Bush, R. A. B. \& Folger, J. P. (1994). The promise of mediation: responding to conflict through empowerment and recognition. São Francisco, CA: Jossey-Bass.

\section{ADRIANA SCOZ DA CUNHA LIMA}

Psicopedagoga, Terapeuta de Casal e Família, Mediadora de conflitos na família, Coordenadora do núcleo de mediação do Instituto Noos, São Paulo,

Email: adrianaclima67@gmail.com

\section{MARIA GABRIELA MANTAUT LEIFERT}

Psicóloga Clínica, Terapeuta Casal e Família e Mediadora.

Coordenadora do Núcleo de Mediação NOOS

Coordenadora da Clínica Social RAV

Email: mgmleifert@gmail.com

\section{ROBERTO RICARDI COSTARD}

Terapeuta de Família e Casal, Mediador de Conflitos, Coordenador do núcleo de mediação do Instituto Noos, São Paulo, E-mail:beto costard@hotmail.com 